\title{
FRAMING CANADIAN FEDERALISM
}

Historical Essays in Honour of John T. Saywell

Framing Canadian Federalism assembles an impressive range of scholars to consider many important issues that relate to federalism and the history of Canada's legal, political, and social evolution. Covering topics such as the Supreme Court of Canada, changing policies towards human rights, First Nations, as well as the legendary battles between Mitchell Hepburn and W.L. Mackenzie King, this collection illustrates the central role that federalism continues to play in the Canadian polity.

Editors Dimitry Anastakis and P.E. Bryden and the volume's contributors demonstrate the pervasive effects that federalism has on Canadian politics, economics, culture, and history, and provide a detailed framework in which to understand contemporary federalism. Written in honour of John T. Saywell's half-century of accomplished and influential scholarly work and teaching, Framing Canadian Federalism is a timely and fitting tribute to one of the discipline's foremost thinkers.

DIMITRY ANASTAKIS is an associate professor in the Department of History at Trent University.

P.E. BRYDEN is an associate professor in the Department of History at the University of Victoria. 


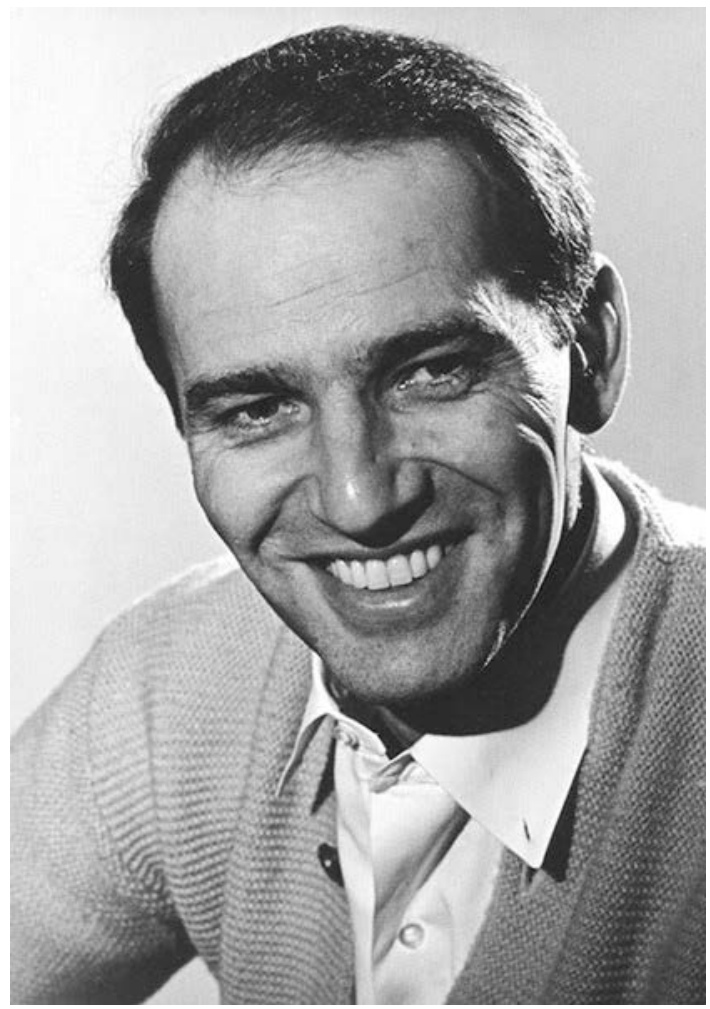

John T. Saywell 


\section{EDITED BY DIMITRY ANASTAKIS AND P.E. BRYDEN}

\section{Framing Canadian Federalism}

\section{Historical Essays in Honour of John T. Saywell}

UNIVERSITY OF TORONTO PRESS Toronto Buffalo London 
(C) University of Toronto Press Incorporated 2009

Toronto Buffalo London

www.utppublishing.com

Printed in Canada

ISBN 978-0-8020-9193-2 (cloth)

ISBN 978-0-8020-9436-0 (paper)

(क)

Printed on acid-free paper

\section{Library and Archives Canada Cataloguing in Publication}

Framing Canadian federalism : historical essays in honour of John T. Saywell / edited by Dimitry Anastakis and P.E. Bryden.

Includes bibliographical references and index. ISBN 978-0-8020-9193-2 (bound) ISBN 978-0-8020-9436-0 (pbk.)

1. Federal government-Canada. 2. Canada - Politics and government. I. Anastakis, Dimitry, 1970- II. Bryden, Penny III. Saywell, John, 1929JL27.F72 $2009 \quad 320.471 \quad$ C2008-907727-X

University of Toronto Press acknowledges the financial assistance to its publishing program of the Canada Council for the Arts and the Ontario Arts Council.

University of Toronto Press acknowledges the financial support for its publishing activities of the Government of Canada through the Book Publishing Industry Development Program (BPIDP).

This book has been published with the help of a grant from the Canadian Federation for the Humanities and Social Sciences, through the Aid to Scholarly Publications Program, using funds provided by the Social Sciences and Humanities Research Council of Canada. 